ANNOUNCEMENTS

CALL FOR PAPERS

1972 WESTERN FINANCE ASSOCIATION MEETINGS

The Annual Meetings of the Western Finance Association will be held at the University of Santa Clara, Santa Clara, Calffornia toward the end of August 1972. Those wishing to submit papers for possible presentation are requested to send nine coples of a slx-page summary of the (planned or finished) paper by January 7, 1972, to the Cha1rman of the Program Committee, who is:

Professor David K. Eiteman

Graduate School of Management

University of California, Los Angeles

Los Angeles, Callfornia 90024.

The Program Comolttee will review all summary papers, and prospective participants will be notified of the acceptance or other disposition of their papers in March 1972.

Abstracts of all papers presented at the August meetings will be published in the March 1972, Proceedings Issue of the Journal of Financlal and Quantitative Analysis. Subsequent to the meetings, participants may submit their full paper to the Journal of Financlal and Quantitative Analysis for publication in lieu of the abstract.

\title{
FOREIGN SUBSCRIPTION RATE CHANGE
}

Effective July 1, 1971, subscription rates for individuals and Iibraries outside the United States (except Canada) are $\$ 11.00$ a year for individuals and $\$ 16.00$ a year for libraries. 